\title{
Quality management during closure works at the Telfer mine: a case study
}

\author{
E Smedley Mine Earth Pty Ltd, Australia \\ B Stokes Newcrest Mining Ltd, Australia \\ M Gallacher Newcrest Mining Limited, Australia \\ S Mackenzie Mine Earth Pty Ltd, Australia
}

\begin{abstract}
The Telfer gold-copper mine is located in the East Pilbara region of Western Australia and is owned by Newcrest Mining Ltd. Newcrest has invested considerable time, cost and effort into mine closure planning throughout the life-of-mine. A major program of closure works is currently being undertaken at Telfer including waste rock landform reshaping, drainage management and revegetation works.

Robust closure designs and documentation have been developed to support effective closure works at Telfer; a key component of this documentation is the specification of construction standards. A quality management program has been developed and implemented to verify that closure works have been completed in accordance with the specified construction standards or to identify where remedial works are required. An important characteristic of the quality management program is that it can be employed without undue impact upon critical path for the closure works.

This paper explores the quality management controls that have been implemented at Telfer and their efficacy in achieving a high standard for closure works.
\end{abstract}

Keywords: closure implementation, management, rehabilitation

\section{Introduction}

Newcrest Mining Ltd (Newcrest) own and operate the Telfer gold-copper mine (Telfer). Telfer is located in the East Pilbara region of Western Australia, approximately 260 km east of Marble Bar within the Great Sandy Desert. Mining commenced at Telfer in 1977 and has included both open cut and underground mining operations. The operations consist of two main open pits, several waste rock dumps (WRDs), one active and one decommissioned tailings storage facility, heap leach facilities, run-of-mine pads and supporting processing and non-processing infrastructure.

In 2017, Newcrest commenced the current program of progressive closure works on several WRDs at Telfer. Detailed closure designs and documentation were developed for the WRD rehabilitation areas, which included a range of drainage management controls. Documentation included the WRD design surfaces, bill of quantities and workpacks. Newcrest has implemented a quality management process for all closure works.

This paper explores common issues with closure works, what quality management measures need to achieve during closure works, and presents a case study describing the quality management process implemented during the closure works at Telfer.

\section{Background}

Regulatory and community expectations for mine closure are that disturbance areas are designed, constructed and rehabilitated in such a manner that they result in limited impact to surrounding areas over many years (often in the order of centuries). 
To meet community and regulatory expectations, the closure design process for constructed mining landforms has increasingly adopted engineering principles from civil, drainage and dam engineering. This includes designing water management controls around specific return events and increased incorporation of design standards. Despite significant improvements in the closure planning and design process, comparable levels of controls are not necessarily applied during closure works. This can result in closure works that do not conform with design requirements and subsequently do not meet post-closure performance requirements. This can result in increased post-closure maintenance and repair costs, decreased rehabilitation success and reduced likelihood of lease relinquishment.

Most guidelines used to inform mine closure place a large emphasis on the closure planning process and post-closure activities but provide little guidance as to how to prepare for and undertake closure works. For example, the International Council on Mining and Metals (ICMM) (2018) includes information on closure planning, monitoring and relinquishment, but a single page on closure works. In addition, there is no guidance on managing the quality of works. All too often, the high standard applied to closure planning and design is not reflected in closure works.

Quality management measures are activities or controls employed to achieve an acceptable standard of quality for works. They can be adopted to improve closure works such that constructed features function for their intended purpose and design life while also reducing the requirement for rework. Quality management measures can also provide the basis of documentation to provide evidence to stakeholders that works have been completed in alignment with approved designs. Quality management measures can be divided into quality planning, quality assurance, quality control and continual improvement. Of importance during closure earthworks are quality assurance and quality control (Furst 2015), and these are the focus of this paper.

Quality assurance refers to processes put in place to achieve acceptable quality during closure works. In its essence, quality assurance is process oriented and aims to prevent issues; it is a proactive quality management process. Examples of quality assurance processes during closure works include verification of contractor competence and global positioning system (GPS) machine guidance.

Quality control refers to activities that ensure quality closure works are completed. Quality control activities are reactive in nature and aim to identify any defects within the finished product and where remedial work is required. Examples of quality control activities during closure works include survey verification and inspection.

\section{Common issues during closure works}

Critical to most closure designs for constructed mining landforms is that they can effectively manage drainage. Controls implemented to manage drainage at closure are typically analogous to open stormwater channels (i.e. conveying surface water), weirs (overtopping of large events) and dams (water storage). Table 1 presents the effective service life expectancy for a range of drainage controls; these assume construction to a typical standard and standard maintenance (McLuckie et al. 2016). Given that in most mine closure scenarios there is limited opportunity for ongoing maintenance, and that controls are typically constructed using available materials, ensuring that closure works are completed to a high standard is critical to maximise the service life of constructed features. Even minor defects in closure works can result in large impacts to the effective service life expectancy, as defects become weak points that can initiate failure and compromise performance of the controls.

Table 1 Typical effective service life expectancy (McLuckie et al. 2016)

\begin{tabular}{ll}
\hline Infrastructure & Effective service life expectancy \\
\hline Open stormwater channels & $10-100$ years \\
Weirs & $40-200$ years \\
Dams & $50-500$ years \\
\hline
\end{tabular}


Common defects during closure works on constructed mining landforms include batter profiles steeper or shallower than design, berm areas of inadequate width or backslope, uneven spreading or insufficient coverage of rock armour or growth media, drainage concentration on flat surfaces and ripping off contour. All these defects have the potential for a deleterious impact upon closure outcomes and should be considered in a quality management program. Defects can occur for a range of reasons including unexpected material behaviour, inexperienced operators, inadequate supervision, inappropriate machines, insufficient controls or unclear design requirements.

\section{$4 \quad$ Quality management considerations}

Quality management measures should be structured to balance the needs of effective project delivery and appropriate closure outcomes. To be effective, quality management should provide assurance that works will be completed to an acceptable standard and meet the design intent while not causing undue cost and schedule impacts. To define an acceptable standard, it is common practice to develop construction standards for works, including construction tolerances. Nominated construction standards should reflect the degree of sensitivity that can be accommodated within the design before the function of the control is compromised. Understanding the rationale behind the different controls, and the risk associated with variance from the design, is important in establishing the appropriate level of quality management required for the works.

Mine closure earthworks typically include a higher degree of unknowns than many other civil works. Given the remote location of many mine sites, closure works are typically undertaken using locally sourced materials and existing mine waste, as opposed to materials sourced from a quarry to meet a given specification. Mine waste is often placed in an ad hoc manner (Figure 1), and there can be a high degree of variability in material types that can present additional challenges to mine closure works and require changes to the design. It is therefore prudent to allow a degree of flexibility within the quality management process to enable an agile response to changing or unexpected conditions, while ensuring that works still meet the design intent.

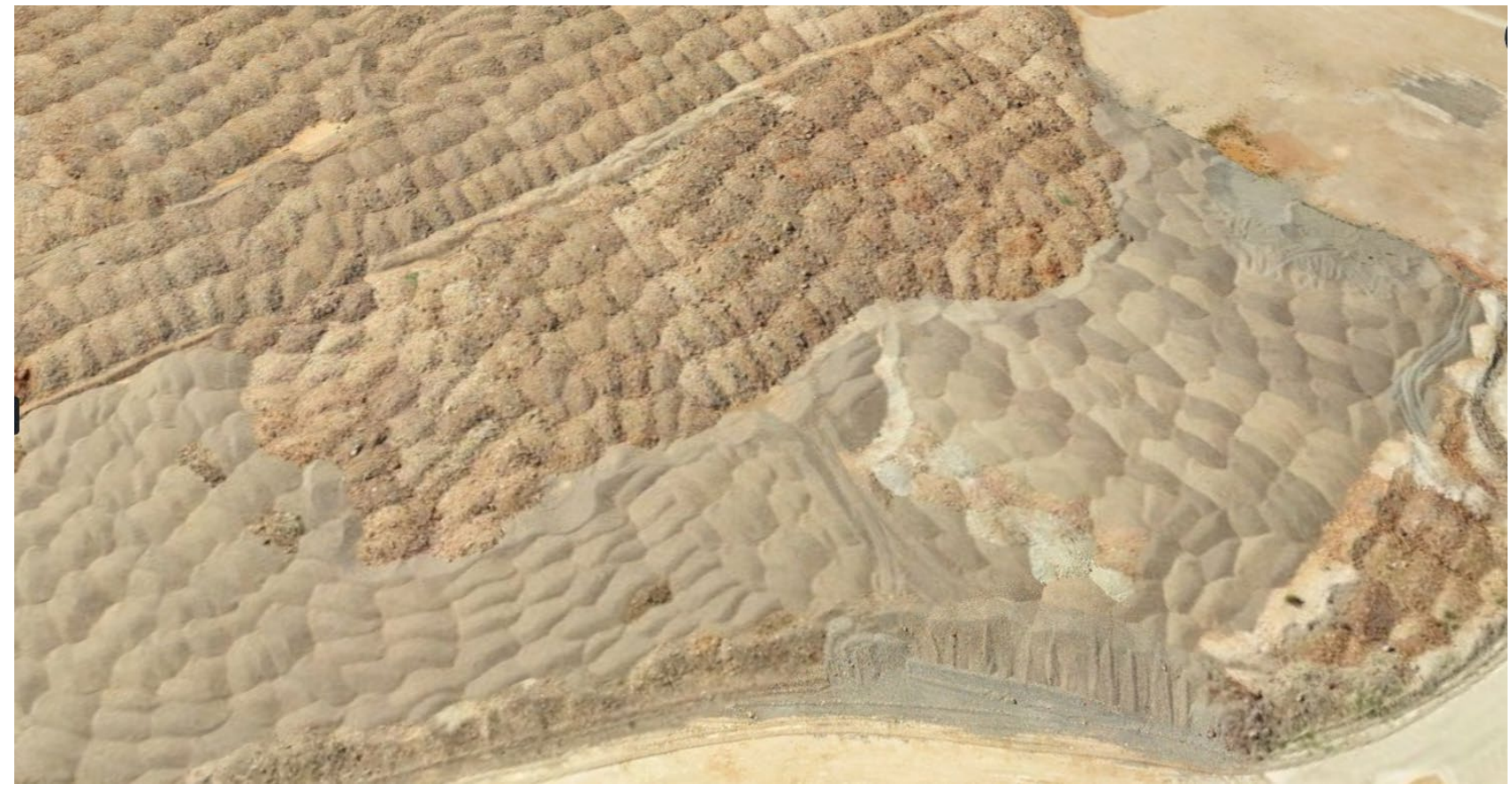

Figure 1 Example of variability in as-dumped mine waste 


\section{$5 \quad$ Case study}

Newcrest implemented a range of quality management measures during WRD closure works at Telfer. A description of the closure works, the quality assurance and quality controls that were applied, and the findings/observations, are presented in the following sections.

\subsection{Closure works}

Progressive closure works have been undertaken across three WRDs at Telfer. This case study focuses on the closure works undertaken at waste dump 6 (WD6) and specifically at the WD6L-E panel on WD6 (Figure 2).

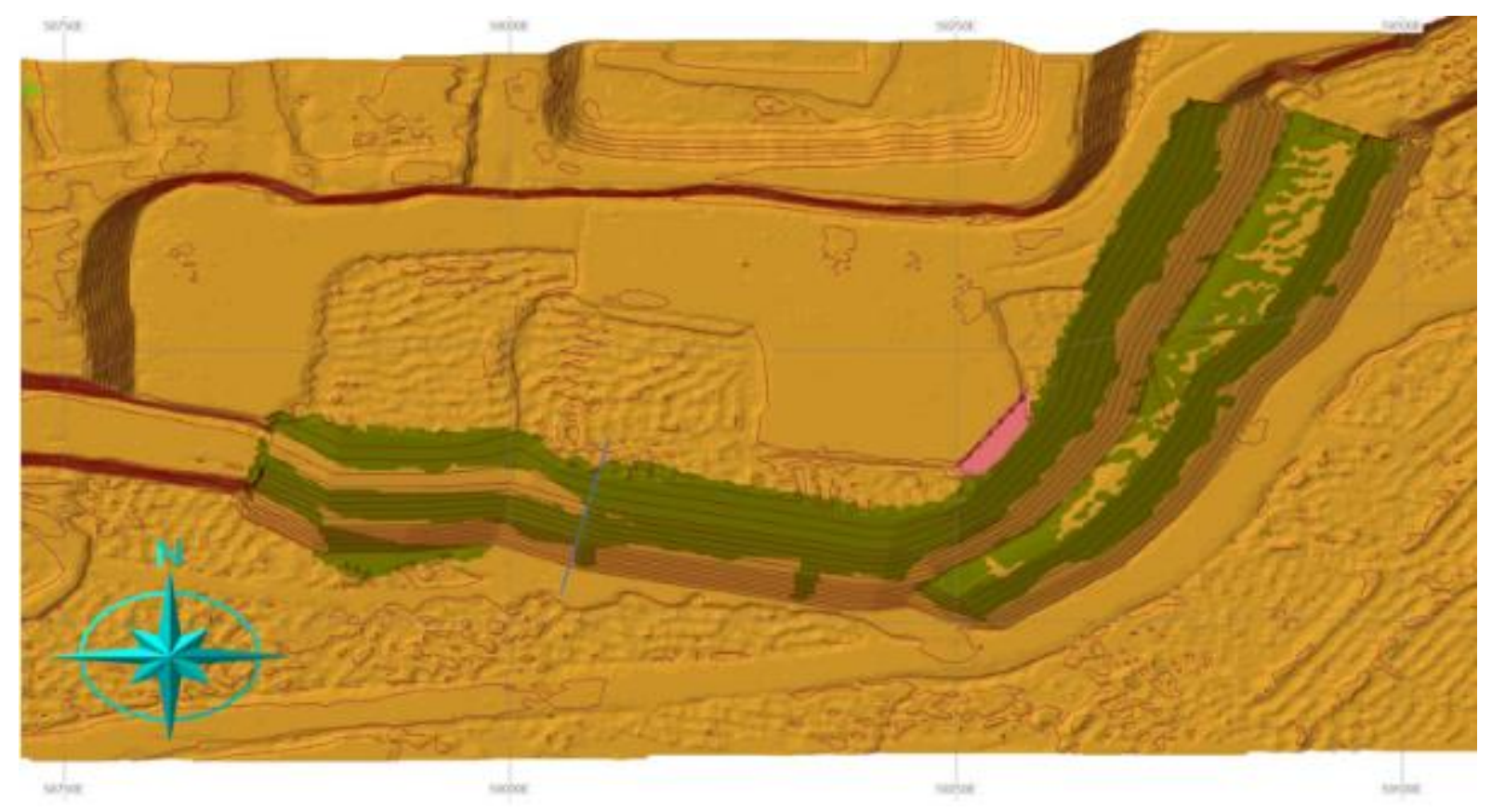

Figure 2 WD6L-E batter and berm closure design

A closure design was developed for WD6L-E. Drainage modelling was completed to inform the sizing of drainage controls. Using the results of the drainage modelling as design parameters, earthworks modelling was completed using the existing surface to develop a design surface for the WRD batter and berm. Designs were developed for different surface treatment trials and drainage control sections and details were prepared. A work breakdown structure (WBS) was developed for each individual task that allowed for detailed cost estimation and tracking. The workpack specified the detailed requirements for each WBS item including relevant construction standards.

There were several unusual challenges at WD6L-E that had the potential to impact upon closure works:

- The top WRD surface level displayed a large degree of variability $( \pm 4 \mathrm{~m})$.

- Materials at WD6L-E ranged from fine-grained highly erodible weathered siltstone to coarse angular durable quartzite rock. Prior to WRD batter reshaping, the siltstone could appear to be coarse and durable, but during reshaping works/dozing, it displayed low-resistance degradation.

- Most of the WRD top surface consisted of paddock dumped rock (Figure 1). Paddock dumped rock was also positioned at the toe of the WRD. Waste rock types were variable and included mill scats, durable quartzite rock and erodible siltstone rock.

- The geometry of the WRD dictated that part of the final batter surface could be constructed as a single lift and part could be constructed in two lifts separated by a $20 \mathrm{~m}$ wide berm. The transition between the two batter sections required close attention during closure works. 
- Following the WRD as-constructed survey utilised for the detailed closure design, a stockpile of paddock dumped rock at the toe of the WRD was removed.

The WD6L-E works area was divided into several zones to trial different construction methods and surface treatments in implementing the closure design. The trials included surface treatment works (including armouring and ripping, rock mulch, and scarification), soil treatment depths and armouring approaches.

\subsection{Quality assurance measures}

Quality assurance measures are those that increase the likelihood that closure works will conform with the design specifications. The quality assurance measures applied at Telfer were broadly grouped into workforce, documentation, supervision, and field measures.

\subsubsection{Workforce measures}

Workforce measures were adopted to ensure that the contractor was suitably experienced in undertaking closure works and proposed to deploy appropriate machines to complete the works. Closure earthworks typically require higher standards than bulk-mining earthworks, and contractor expertise has a strong bearing on the final outcome and quality of closure works.

Recent and relevant closure experience was a key requirement for selecting the preferred contractor for works. Proven closure experience is critical for project managers, supervisors, leading hands and key machine operators (typically dozers and excavators).

Fleet selection was also a key consideration as this has implications for cost and works quality. For example, adopting a large dozer, such as a D11, is likely to result in a lower unit rate for bulk reprofiling; however, achieving fine construction tolerances and accurate contour ripping is difficult with a D11. Further, load and haul fleets should consider the total volumes of load and haul, accessibility and the average haul distances to optimise fleet composition.

Consideration should also be given to the requirement for GPS machine control during closure works. GPS machine control can reduce the reliance on survey resources and help address limitations in operator expertise. GPS machine control was not utilised during closure works at WD6L-E; however, Newcrest intends to incorporate this into future rehabilitation projects to reduce the need for ongoing survey support for mark outs etc.

\subsubsection{Documentation measures}

Documentation measures include the design information, instruction and construction standards to the contractor.

The workpack was the primary documentation measure for the works and consisted of the detailed design surface and strings, detailed sections, specifications, WBS, bill of quantities, roles and responsibilities, preferred construction methods and construction standards. The workpack also identified hold points that required signoff before undertaking subsequent tasks. The workpack included signoff boxes for each WBS item, to be completed once the works had been undertaken to an acceptable standard.

The WD6L-E area was divided into a series of zones that enabled signoff to be achieved for various hold point areas without impacting upon critical path.

Construction standards were established with the aim of verifying that works met the design intent. This enabled flexibility in the works and avoiding the need for rework to meet the design surface even if this would achieve no additional improvements in the outcomes (or potentially produce a worse outcome due to additional mechanical weathering of surface materials). To incorporate flexibility within the construction standards, the workpack adopted discretionary construction standards for some works. For example, for reprofiling of WRD batters, compliance could be achieved by conformance with a $\pm 200 \mathrm{~mm}$ tolerance to the survey or by a tolerance of $\pm 1^{\circ}$ in section along the batter surface. Higher construction standards were 
employed where the potential consequence of failure would be greater (e.g. water storage controls on flat surfaces, rock armouring thickness). The construction standards adopted for the works are presented in Table 2; these should always be developed for site specific conditions and to reflect the requirements of the closure design.

There can be a large degree of uncertainty during closure works and change management is an important consideration. The workpacks were structured to be a living document. A change management process was implemented so that when Newcrest or the contractor considered that a change to the design was required, a change notice could be developed and embedded within the workpack. The change notice was required to state the purpose of the change, the nature of the change, the WBS items impacted (or new WBS items to be created) and the impact upon the bill of quantity.

\section{Table 2 Construction standards for WD6L-E}

\begin{tabular}{|c|c|c|}
\hline Activity & Standard & Notes \\
\hline Outer batter & $\begin{array}{l} \pm 200 \mathrm{~mm} \text { of design surface OR } \\
\pm 1^{\circ} \text { of the design slope angle }\end{array}$ & $\begin{array}{l}\text { Audit to verify neat trim of } \\
\text { final surface. }\end{array}$ \\
\hline Berms & $\begin{array}{l} \pm 100 \mathrm{~mm} \text { variance along the crest level AND } \\
\pm 150 \mathrm{~mm} \text { variance in the difference between the } \\
\text { design crest } R L \text { and the } R L \text { of the toe line of the } \\
\text { upper slope when compared with design }\end{array}$ & \\
\hline $\begin{array}{l}\text { Rock } \\
\text { armour/rocky } \\
\text { mulch }\end{array}$ & $\begin{array}{l}\text { Average cover thickness along the armoured area } \\
\text { to be within } \pm 15 \% \text { of the design AND } \\
\text { Cover thickness to be within } \pm 20 \% \text { of the design } \\
\text { surface across } 80 \% \text { of the treated area* }\end{array}$ & $\begin{array}{l}* \text { Where the cover material has } \\
\text { a } d_{50} \text { where } 0.5 \times d_{50} \text { is greater } \\
\text { than } 20 \% \text { of the cover } \\
\text { thickness, the construction } \\
\text { tolerance will instead be } \\
0.5 \times d_{50} \text { of the cover material. } \\
\text { For example, if a rock with } d_{50} \\
\text { of } 300 \mathrm{~mm} \text { was used for a } \\
500 \mathrm{~mm} \text { cover, the } \\
\text { construction tolerance would } \\
\text { be } \pm 150 \mathrm{~mm} \text { not } \pm 100 \mathrm{~mm} \text {. }\end{array}$ \\
\hline Soil & $\begin{array}{l}\text { Average soil thickness along the treated area to be } \\
\text { within } \pm 15 \% \text { of the design AND } \\
\text { Soil thickness to be } \pm 100 \mathrm{~mm} \text { of the design surface }\end{array}$ & $\begin{array}{l}\text { Where soil is placed over } \\
\text { coarse rock with large voids, } \\
\text { measure volume on imported } \\
\text { quantity, not spread due to } \\
\text { high interstitial losses. }\end{array}$ \\
\hline Crest windrow & $\begin{array}{l} \pm 150 \mathrm{~mm} \text { variance on the crest top surface RL AND } \\
\pm 1^{\circ} \text { of the design slope angle }\end{array}$ & $\begin{array}{l}\text { Minimum crest level defined at } \\
\text { lowest point in the cell. }\end{array}$ \\
\hline Cell bunds & $\begin{array}{l} \pm 100 \mathrm{~mm} \text { variance on the crest top surface RL AND } \\
\pm 1^{\circ} \text { of the design slope angle }\end{array}$ & \\
\hline
\end{tabular}

\subsubsection{Supervision measures}

Effective supervision is a key determinant of successful closure works. Supervision roles included the contractor's supervisor who should be always onsite during works and the Newcrest's representative who should be inspecting works on a regular basis. Effective supervision greatly reduces the risk of misinterpretation of the design but also enables the realisation of opportunities to improve the closure 
works, such as identifying problematic or beneficial materials early or potential improvements to the construction method.

For closure works at WD6L-E, the contractor utilised supervisors with extensive closure experience who were supported by a leading hand and a project manager. The contractor supervisor would direct and guide operators, assess and maintain works quality, manage health, safety and environmental issues, and work to maintain adequate serviceability of the fleet. Generally, the contractor supervisor was the first to identify issues with the works that required the attention of the Newcrest representative.

The Newcrest project team included the project owner/superintendent, design engineer and project supervisor, which helped maintain the integrity of the design intent in the event of changes to the design. The Newcrest closure project team undertook regular inspections of the works. The team would assess and audit the adequacy of works, advise where remedial works were required, coordinate site support services, undertake compliance checks and facilitate change management.

The contractor supervisors and the Newcrest project team worked together to verify that works achieved a high standard and to ensure that combined resources were coordinated to limit potential impacts to critical path.

\subsubsection{Field measures}

A wide range of field measures were deployed to manage quality during the earthworks. Field measures included survey layout, survey pickups, laser-levelling, clinometers, test ripping (see Figure 3 ) and seeding calibration. Quality assurance field measures for the major activities are presented in Table 3.

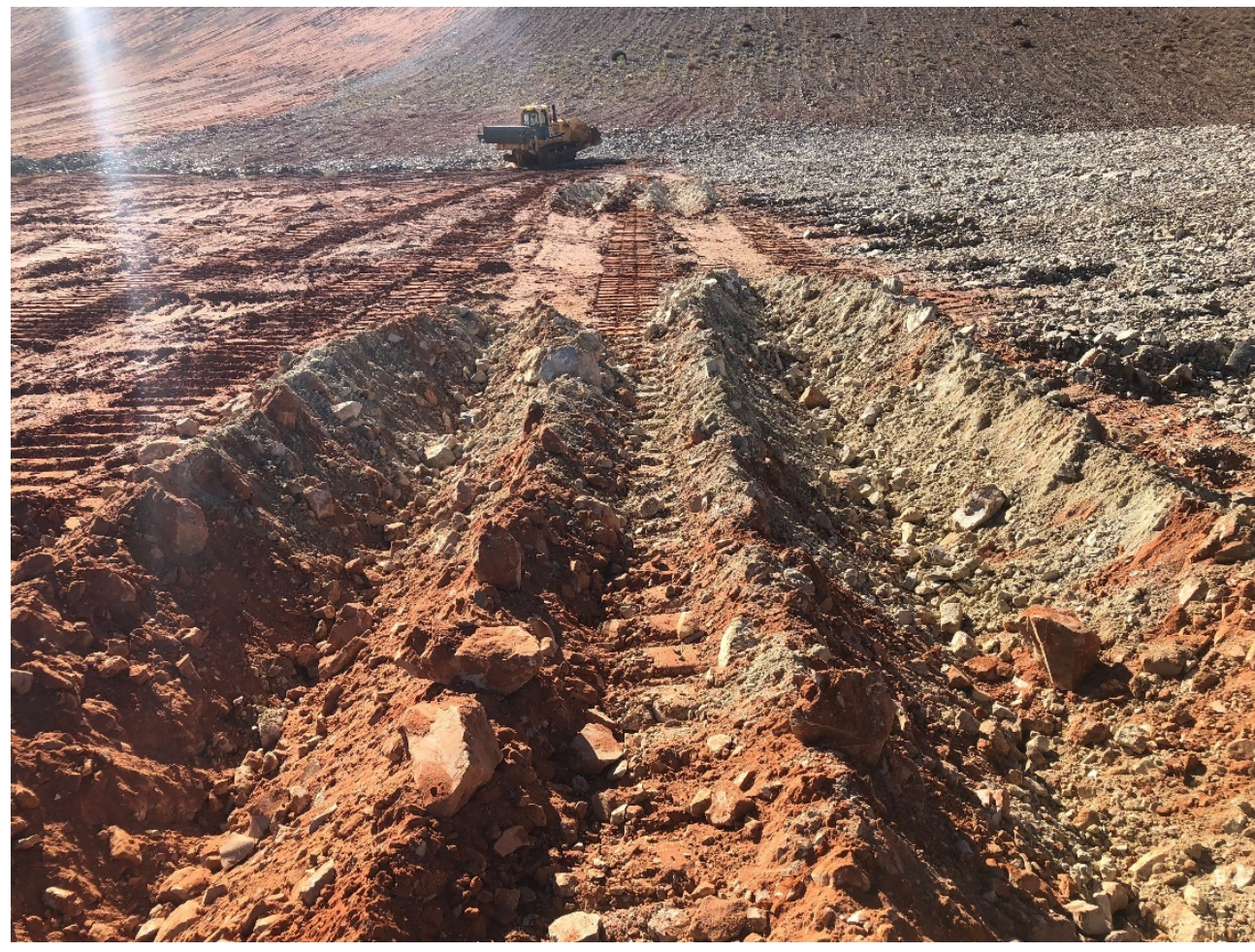

Figure 3 Test ripping at various depths to assess the optimal depth 
Table 3 Quality assurance field measures for WD6L-E

\begin{tabular}{|c|c|}
\hline Works activity & Quality assurance field measures \\
\hline Reprofile batters & $\begin{array}{l}\text { - Survey layout using pegs at the crest, toe and point of inflection } \\
\text { - Dozer clinometer } \\
\text { - Regular survey pickups }\end{array}$ \\
\hline Rock armour application & $\begin{array}{l}\text { - Inspection of rock armour sources } \\
\text { - Pegs marked to target depth } \\
\text { - Truck number counting } \\
\text { - Survey pickups }\end{array}$ \\
\hline Topsoil application & $\begin{array}{l}\text { - } \text { Truck number counting } \\
\text { - } \quad \text { Pegs marked to target depth } \\
\text { - Survey pickup }\end{array}$ \\
\hline Contour ripping & $\begin{array}{l}\text { - Test rips to assess suitable ripper location for material (Figure 3). } \\
\text { Mark the shank at the target ripping depth } \\
\text { - Laser-level with pegs positioned at the centre of the top rip line } \\
\text { (reset level every } 10 \text { rip lines) } \\
\text { - Dozer clinometer }\end{array}$ \\
\hline Mechanical seeding & $\begin{array}{l}\text { - Calibration of spigots based upon the observed seeding rate } \\
\text { per hectare } \\
\text { - Visual inspection of the seeding area }\end{array}$ \\
\hline Flat surface reshaping & $\begin{array}{l}\text { - } \text { Laser-level } \\
\text { - Survey layout } \\
\text { - } \quad \text { Survey pickup }\end{array}$ \\
\hline Bund construction & $\begin{array}{ll}\text { - } & \text { Survey pickup } \\
\text { - } & \text { Laser-level }\end{array}$ \\
\hline
\end{tabular}

\subsection{Quality control measures}

The primary quality control measures employed during closure works at Telfer included survey pickup and inspections. Following the completion of each WBS item, the relevant area would be inspected and surveyed (if appropriate) to verify that the works were completed in accordance with the design.

Survey pickups were undertaken using an unmanned aerial vehicle (UAV) with Smart Ground Control Points to reduce the reliance on Telfer survey resources and to ensure a fast turnaround time (Figure 4). Utilising a UAV and Smart Ground Control Points also minimised the amount of machine downtime associated with traditional ground-based surveying techniques. UAV survey data was processed using photogrammetry software and uploaded to a spatial data analytics platform (the platform). The platform was a cloud-based system, meaning that the orthophotos, digital elevation models and other spatial datasets were viewable by the entire project team and could be used to clearly demonstrate where remedial works were required to be undertaken by the contractor. 


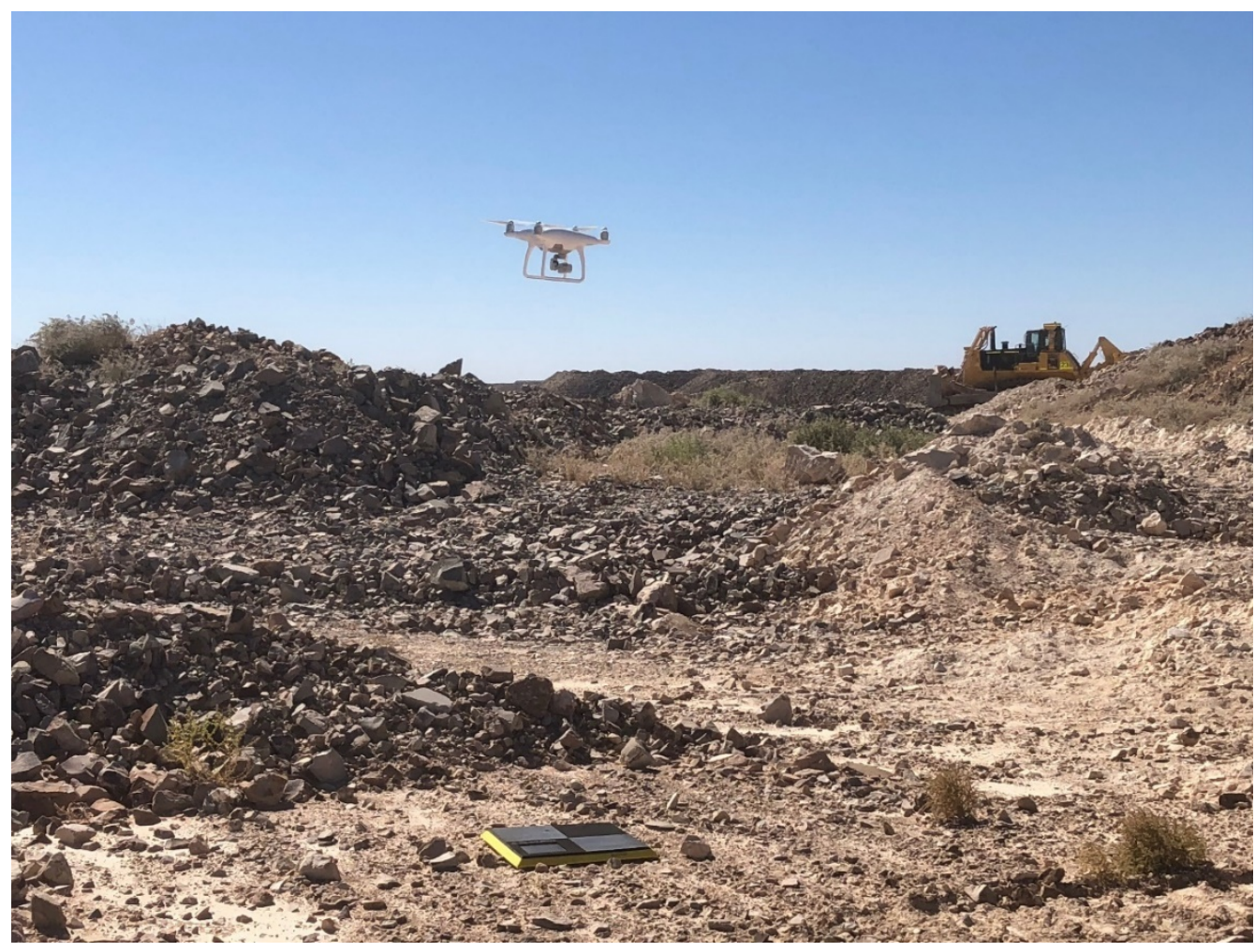

\section{Figure 4 UAV and Smart Ground Control Point}

The platform included a range of inbuilt tools that are well suited to construction assessment and verification of works (Figure 5 and Figure 6). These tools were utilised to undertake compliance assessments of each step of the closure works.

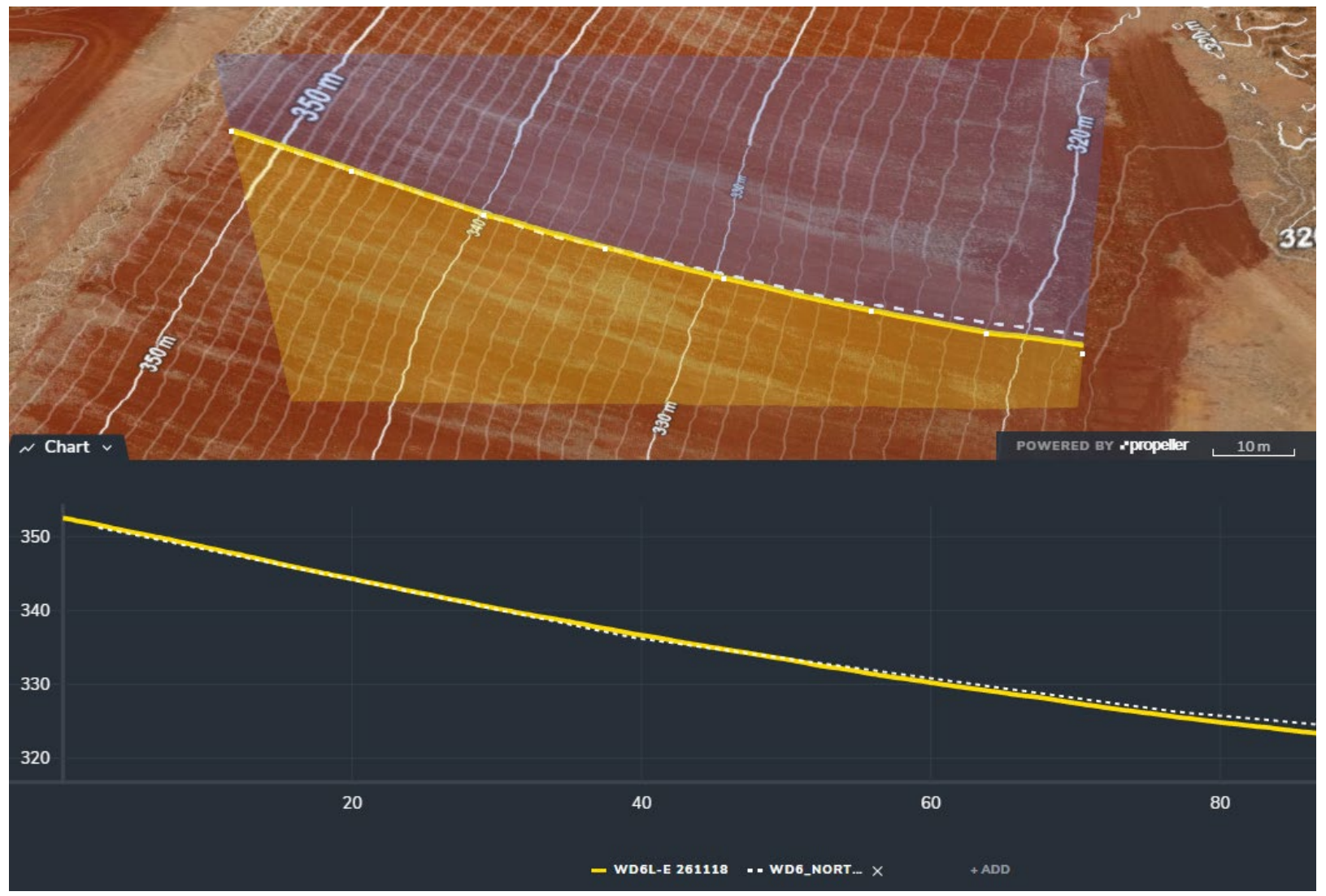

Figure 5 Example cross-section assessment of a reprofiled WRD at WDL6L-E 


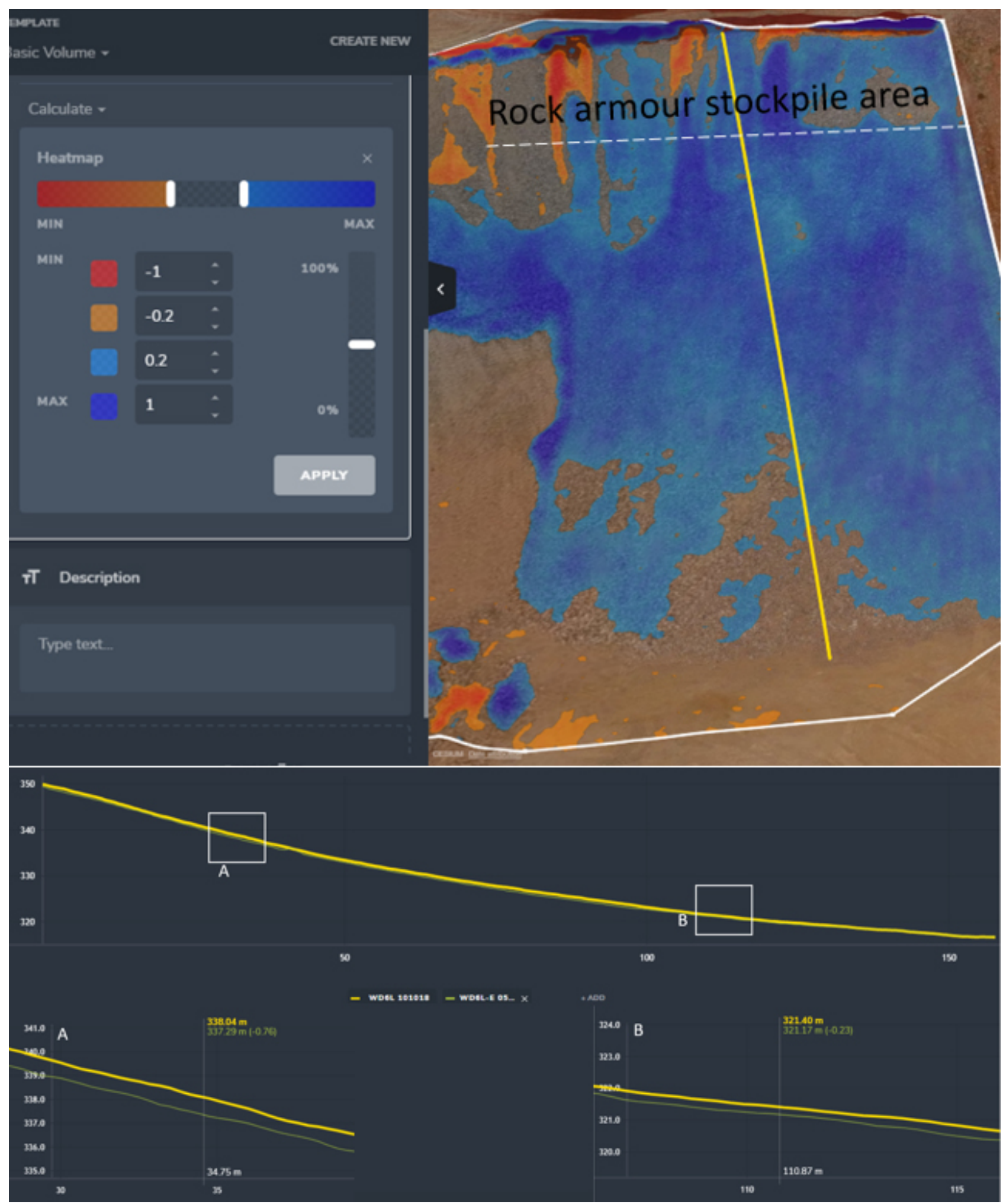

Figure 6 Example cross-section assessment of armour thickness. The assessment identified that there was a shortfall of armour at the lower half of the WRD batter and additional material was required 
In addition to the survey assessment, works were inspected by the Newcrest project team to certify that they had been completed in accordance with the requirements and to determine whether remedial works were required. These inspections were important as they not only confirmed whether the works met the construction standards, but they enabled the Newcrest project team to determine that the actual conditions encountered were consistent with the assumptions incorporated into the design. For example, some of the substrate material that was expected to have high-stability properties had undergone considerable mechanical weathering due to reprofiling works. The resulting reduced fragment size meant that additional rock armour was required to enhance the erosional stability of the surface, and the design was amended. Reliance on survey alone would not have identified this issue, as the works themselves met the construction standard.

Once works were completed to meet the required construction standards, the task in the workpack was signed off by the Newcrest and contractor representatives.

Once all works were completed, an as-built survey was undertaken and a closure works conformance report was prepared to verify that all works had been completed in accordance with Newcrest's commitments.

\subsection{Observations}

The quality management measures implemented by Newcrest at WD6L-E were effective to ensure that closure works met the required standards (Figure 7). The contractor was aware of the construction standards that it was expected to meet. The contractor, in turn, was able to advise Newcrest when inspections and surveys were required to avoid impact to critical path. Defects were identified and addressed in a timely manner.

The quality control measures applied worked as an effective tool to manage survey data and to assess compliance to the nominated construction tolerances. The use of Smart Ground Control Points enabled the Newcrest project team to quickly respond to survey requirements during works. Using a cloud-based platform meant that all members of the project had access to survey information.

Future quality management improvements identified include increased use of GPS machine control and additional delineation of roles and responsibilities. The potential to incorporate improved survey technology such as real-time kinetic equipped drones will also be explored.

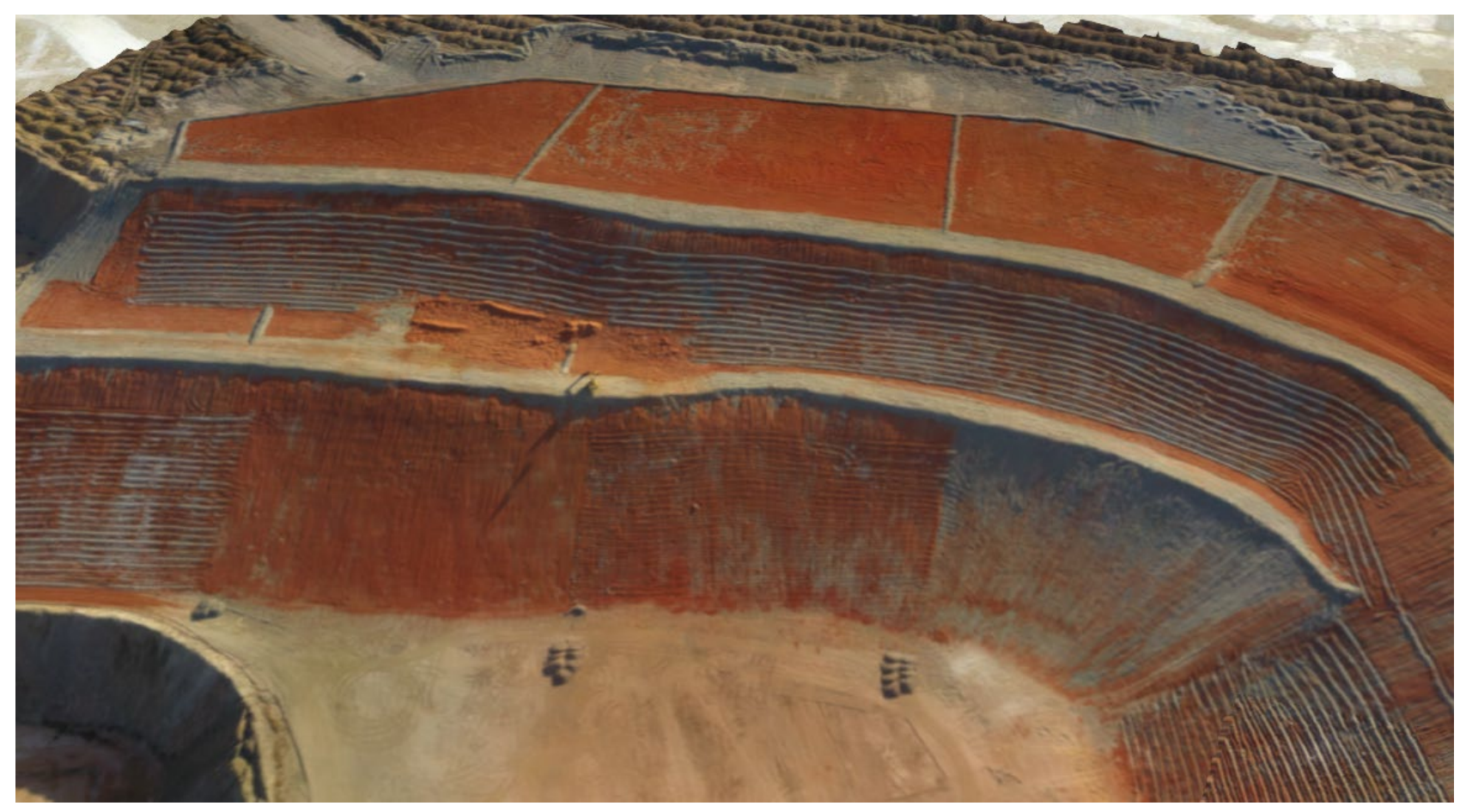

Figure 7 Orthophoto of largely completed works at the eastern side of WD6L-E 


\section{Conclusion}

Quality management (specifically quality assurance and quality control) measures during closure works at Telfer were employed to ensure that works were completed to a high standard and met the intent of the closure design. Quality management measures were structured to achieve a high quality of works with minimal impact to critical path.

Key quality assurance measures implemented at Telfer included appointing contractors with relevant and proven experience, appropriate fleet selection, clear and comprehensive design documentation, effective supervision, and utilisation of necessary field control measures. Discretionary construction standards were built into the quality assurance measures to provide flexibility in achieving the design intent.

Quality control measures were effective at ensuring the works met the construction standards. Using Smart Ground Control Points and UAV survey greatly improved workflow processes and reduced potential impacts to critical path. Inspections were completed to verify that works were completed to an acceptable standard and that the actual conditions were consistent with the assumed conditions incorporated into the closure design.

\section{References}

Furst, P 2015, Construction Quality Management, International Risk Management Institute, Dallas, viewed 17 March 2018 , https://www.irmi.com/articles/expert-commentary/construction-quality-management

International Council on Mining and Metals 2018, Integrated Mine Closure - Good Practice Guide, 2nd edn, London, viewed 17 March 2018, https://guidance.miningwithprinciples.com/integrated-mine-closure-good-practice-guide/

McLuckie, D, Thomson, R, Drynan, L \& Toniato, A 2016, 'Risk based design', Chapter 5 in Book 8 of Australian Rainfall and Runoff - A Guide to Flood Estimation, Commonwealth of Australia, Canberra. 